\title{
Uterine Corpus Adenosarcoma pT2 TNM
} Finding v8

National Cancer Institute

\section{Source}

National Cancer Institute. Uterine Corpus Adenosarcoma pT2 TNM Finding v8. NCI

Thesaurus. Code C139857.

Uterine corpus adenosarcoma with tumor extending beyond the uterus, within the pelvis.

(from AJCC 8th Ed.) 